Frederik KORTLANDT

Leiden University

\title{
BALTO-SLAVIC ACCENTUATION: SOME NEWS TRAVELS SLOWLY
}

Since 1973 I have been advocating the view that the Balto-Slavic acute tone was in fact glottalic and has been preserved unchanged in originally stressed and unstressed syllables in Žemaitian and Latvian, respectively (e.g. 1975, 1977, 1985, 1998). Jay Jasanoff has now (2004) adopted the gist of my view, but without mentioning my name. It may therefore be useful to sketch the background of our differences and to point out the remaining discrepancies.

More than twenty years ago there was a discussion between Jasanoff (1983) and Schmalstieg (1983) about final syllables in Slavic. As I pointed out in my comment (1983), the discussion was strongly reminiscent of the one which almost a century earlier took place between Streitberg (1892) and Hirt (1893), the former author insisting upon tonal distinctions and the latter upon the place of the stress for the explanation of timbre distinctions in final syllables. In his contribution, Jasanoff came up with solutions that had been proposed eighty years earlier by Holger Pedersen (1905) in an article which he evidently had not seen. Some news travels slowly.

In the meantime our knowledge of Slavic accentuation has increased dramatically (cf. Kortlandt 1979 for an introduction). It should be clear by now that there is no evidence for an original prosodic distinction between Indo-European acute and circumflex syllables either in Indo-Iranian, where a hiatus represents an intervocalic laryngeal, or in Greek, where an original circumflex reflects an earlier hiatus from a lost intervocalic laryngeal, or in Germanic, where the difference between short and long reflexes is fully explained in terms of segmental features and well-motivated analogical developments, or in Balto-Slavic, where the acute is a broken tone reflecting Indo-European laryngeals and preglottalized stops (Winter's law) and the circumflex represents lengthened grade and contractions (cf. Kortlandt 1986 for discussion). One may therefore wonder about the motivation for Jasanoff to stick to the neogrammarian assumption of tonal distinctions and to ignore the contrary evidence.

While twenty years ago Jasanoff still invoked a circumflex gen.pl. ending *-óm for Indo-European in order to account for the disyllabic scansion in Vedic $-\bar{a} m$ (-aam), the circumflex tone in Greek -onn, and the long - $o$ in Gothic feminines and elsewhere in Germanic and was eager to find a new way around the BaltoSlavic counter-evidence (1983: 187), he has now (2004: 248f.) abandoned the 
first two pieces of evidence and limited the argument to the Germanic ending. In fact, all Indo-European languages except Greek point to a short gen.pl. ending *-om. Since I have discussed the gen.pl. ending in detail elsewhere (1978, see also 1983: 170-174), I shall not take the matter up again here. Suffice it to say that Jasanoff has not answered the points which I raised in connection with the Germanic data (ibidem). Nor shall I discuss Jasanoff's arbitrary reconstructions $*_{-} \tilde{o}$ and *-on for the masc. nom.sg. ending of Old High German gumo and Gothic guma, respectively (2004: 250).

For Balto-Slavic, Jasanoff now assumes that the loss of the Indo-European laryngeals yielded new long vowels which were subsequently shortened with concomitant glottalization, thus giving rise to a "broken tone" (2004: 251). This superfluous assumption of lengthening and subsequent shortening gets him into difficulties because earlier long vowels (from lengthened grade and contractions) remained distinct from the new long vowels (which arose from the loss of the laryngeals). Jasanoff partly remedies these difficulties by assuming an additional series of lengthenings of earlier long vowels, yielding "hyperlong" vowels. These lengthenings concern (1) long vowels from contractions after the loss of an intervocalic laryngeal (corresponding to the Indo-Iranian hiatus and the Greek original circumflex), then (2) lengthened grade vowels in "absolute final position" which allegedly received an "extra mora of length" following a special ad hoc rule which supposedly operated in both Germanic and Balto-Slavic in order to account for such instances as OHG gumo (but not Gothic guma) and Lith. akmuõ and duktẽ (Jasanoff 2004: 249f.), then after the rise of glottalization (3) Lith. long vowel preterits such as $\tilde{e} j o$ and srëbe "under the influence of related forms" (Jasanoff 2004: 252), then (4) Lith. $i$ - and $u$-diphthongs in final syllables which were not monophthongized such as dat.sg. $-u i<*_{-} \bar{o} i$ and inst.pl. -ais $<*_{-} \bar{o} i s$, and (5) vowels and diphthongs in Slavic mobile paradigms. In spite of the exceedingly high number of special assumptions, there remain a substantial number of counterexamples which Jasanoff does not discuss.

The fact of the matter is that the glottalic feature of the Balto-Slavic "broken tone" is the phonetic reflex of the Indo-European laryngeals (and preglottalization) and that original long vowels (from lengthened grade and early contractions) simply remained long vowels and never became acute. It follows that Jasanoff has missed the following categories (cf. Kortlandt 1986: 154f. and 1997: 26):

(1) Lengthened grade vowels before final resonants which were not lost, e.g. Latvian âbuõls 'apple', SCr. žërā v 'crane', Czech žeráv. These words represent the

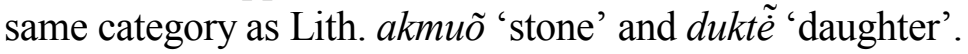

(2) Lengthened grade vowels in the sigmatic aorist, e.g. SCr. $1^{\text {st }} \mathrm{sg}$. donijeh beside donèsoh 'brought', ùmrijeh 'died', zàklēh 'swore'. This category is reflected in 
the East Baltic long vowel preterit, e.g. Lith. srẽ $\dot{b} \dot{e}$ 'sipped', cf. Vedic ásrāk 'emitted'.

(3) Lengthened grade vowels in original root nouns, e.g. Lith. gèlà 'pain', žolẽ 'grass', mèsà 'meat', SCr. rïječ 'word', čâr 'magic', sâm 'alone', Czech čár, čára, sám. The circumflex reflex of the lengthened grade vowel contrasts with the acute of laryngeal origin in the verb, e.g. Lith. gélti 'ache', SCr. žăliti 'mourn', also Lith. žélti 'grow'.

(4) Lengthened grade vowels before a laryngeal, which was lost. These are found in the following subcategories:

(4a) The $2^{\text {nd }}$ and $3^{\text {rd }}$ sg. form of the sigmatic aorist, e.g. SCr. dâ 'gave' $<* d \bar{o} s$, lî 'poured' $<* l e \bar{e} i s$, as opposed to $1^{\text {st }} \mathrm{sg}$. däh $<* d o H s-$, lïh $<* l e H i s-$, cf. Vedic injunctive stoṣam 'I praise', jeșam 'I conquer', with full grade vocalism (Kortlandt 1987).

(4b) The metatony in the Lithuanian future, e.g. duõs 'will give', liẽs 'will pour', as opposed to bùs 'will be', lìs 'will rain', dialectally also žinõs 'will know', stovẽ s 'will stand', kalbẽ s 'will speak' beside rašìs 'will write', darìs 'will do', sakis 'will say' (Zinkevičius 1966: 361). The metatony reflects the loss of a laryngeal after a lengthened grade vowel in the aorist injunctive, e.g. *dōs, *lèis.

(4c) Root nouns with loss of a laryngeal after a lengthened grade vowel, viz. Latvian sâls 'salt', gùovs 'cow', cf. Lith. sólymas 'brine'.

(4d) The Lith. nom.sg. ending $-\tilde{e}$, which was generalized from the root noun that is represented in arklide 'stable', avide 'sheepfold', alùde 'pub', pelùde 'chaff store', cf. Vedic -dhấ, Latin -dès.

Apart from the totally inadequate presentation of the evidence, Jasanoff gives a mistaken interpretation of several Lithuanian case endings (2004: 253). He claims that dat.sg. $-u i<*_{-} \bar{o} i$ and inst.pl. -ais $<*_{-} \bar{o} i$ s are "only secondarily circumflex" because the acute was lost "in final nuclei that could not be shortened to a single mora" in spite of the fact that they did not attract the stress in accordance with Saussure's law. This is clearly wrong because the $1^{\text {st }}$ and $2^{\text {nd }} \mathrm{sg}$. endings $-a \tilde{u}$ and -aĩ did attract the stress in accordance with Saussure's law before they became circumflex (cf. Kortlandt 1977: 327f.). Moreover, this new circumflex is limited to a part of the Lithuanian dialects only. Contrary to Jasanoff's statement, the Lith. endings -ui and -ais are identical with their Greek cognates -õ $i$ and -oĩs.

Jasanoff states that for "reasons that are still not entirely clear" pronominal nom.pl. *-oi became acute in Balto-Slavic, as reflected in Lith. gerì, gerieji, and appears secondarily as circumflex -ai in nouns, e.g. vilkaĩ. In fact, circumflex -ai is also found with derived adjectives in -is, e.g. auksìniai 'golden', jaunùčiai 'very young', and dialectally in pronominal endings. Elsewhere I have argued that circumflex - $a i$ and acute -ie represent unstressed masculine ${ }^{*}$-oi and stressed neuter *-aH-i, respectively (1994, also 1997: 28f.). These two endings were in complementary distribution after original barytone neuters had become masculines in 
Balto-Slavic. It follows that the acute reflects an Indo-European laryngeal and the circumflex its absence.

For Slavic, Jasanoff maintains that (1) "accented acute vowels came to differ from accented non-acute vowels only in their pitch contour" and (2) "unaccented acute vowels ceased to be phonetically distinguishable from non-acute vowels at all" (2004: 254). Both statements are false. As I have argued in detail elsewhere $(1975,1989)$, the Indo-European laryngeals remained segmental phonemes up to the end of the Balto-Slavic period, were then lost in pretonic and post-posttonic syllables in early Slavic, became a prosodic feature at the time of the monophthongizations, had nothing to do with the rise of phonemic pitch contours, gave rise to new timbre distinctions when the broken tone was lost in posttonic syllables, and eventually gave rise to short rising vowels, as opposed to long rising vowels reflecting the Balto-Slavic circumflex and falling vowels which arose in Slavic mobile paradigms. Thus, Slovene bràt 'brother' and pót 'way' reflect the presence versus absence of a laryngeal (Greek phrätér versus póntos) in the distinction between short and long root vowel, while the falling tone is found in both dâr 'gift' and $v \hat{o} z$ 'carriage' (Gr. dõron vs. ókhos). The distinction between acute (short) and non-acute (long) vowels in posttonic syllables is well preserved in the SCr. suffixes -at, -av, -ica, -ina versus - $\bar{a} r$, -ìk, -ìn, -inna (cf. Dybo 1968), among other instances. Jasanoff adds that the acute was also lost in unaccented syllables in Lithuanian (2004: 254). Again, this is a simplification which holds true for the literary language, but not for the dialects (cf. Aleksandravičius 1957, Grinaveckis 1973).

I conclude that Jasanoff's distorted picture of Balto-Slavic accentuation is a result of insufficient knowledge of the data and the scholarly literature. Some news travels slowly, alas.

\section{REFERENCES}

Aleksandravičius, J. 1957. Kirtis ir priegaidè Kretingos tarmèje. Lietuviu Kalbotyros Klausimai 1, 97-107.

Dybo, Vladimir. 1968. Akcentologija i slovoobrazovanie v slavjanskom. Slavjanskoe jazykoznanie: VI meždunarodnyj s"ezd slavistov, 148-224.

Grinaveckis, Vladas. 1973. Žemaičiu tarmiu istorija (Vilnius: Mintis).

Hirt, Hermann. 1893. Zu den slavischen Auslautsgesetzen. Indogermanische Forschungen 2, 337-364.

Jasanoff, Jay. 1983. A rule of final syllables in Slavic. Journal of IndoEuropean Studies 11, 139-149.

Jasanoff, Jay. 2004. Acute vs. circumflex: Some notes on PIE and post-PIE prosodic phonology. Per aspera ad asteriscos [Fs. Rasmussen], 247-255. 
Kortlandt, Frederik. 1975. Slavic accentuation: A study in relative chronology (Lisse: Peter de Ridder). Also available at [www.kortlandt.nl]

Kortlandt, Frederik. 1977. Historical laws of Baltic accentuation. Baltistica 13/2, 319-330.

Kortlandt, Frederik. 1978. On the history of the genitive plural in Slavic, Baltic, Germanic, and Indo-European. Lingua 45, 281-300.

Kortlandt, Frederik. 1979. On the history of Slavic accentuation. Zeitschrift für vergleichende Sprachforschung 92, 269-281.

Kortlandt, Frederik. 1983. On final syllables in Slavic. Journal of IndoEuropean Studies 11, 167-185.

Kortlandt, Frederik. 1985. Long vowels in Balto-Slavic. Baltistica 21/2, 112124.

Kortlandt, Frederik. 1986. Proto-Indo-European tones? Journal of IndoEuropean Studies 14, 153-160.

Kortlandt, Frederik. 1987. Archaic ablaut patterns in the Vedic verb. Festschrift for Henry Hoenigswald, 219-223.

Kortlandt, Frederik. 1989. Od praindoevropskog jezika do slovenskog (fonološki razvoj). Zbornik za Filologiju i Lingvistiku 32/2, 41-58. English version available at [www.kortlandt.nl]: From Proto-Indo-European to Slavic.

Kortlandt, Frederik. 1994. Tokie šalti rytai. Baltistica 28/1, 45-48.

Kortlandt, Frederik. 1997. PIE. lengthened grade in Balto-Slavic. Festschrift for Eric P. Hamp, vol. II, 26-31.

Kortlandt, Frederik. 1998. The rise and fall of glottalization in Baltic and Slavic. Linguistica Baltica 7, 147-150.

Pedersen, Holger. 1905. Die Nasalpräsentia und der slavische Akzent. Zeitschrift für vergleichende Sprachforschung 38, 297-421.

Schmalstieg, William. 1983. Slavic kamy and mati: A structural view. Journal of Indo-European Studies 11, 151-165.

Streitberg, Wilhelm. 1892. Der Genetiv Pluralis und die baltisch-slavischen Auslautgesetze. Indogermanische Forschungen 1, 259-299.

Zinkevičius, Zigmas. 1966. Lietuviu dialektologija: Lyginamoji tarmiu fonetika ir morfologija (Vilnius: Mintis). 